\title{
Barriers of effective health insurance coverage for rural-to-urban migrant workers in China: a systematic review and policy gap analysis
}

Shanquan Chen', Yingyao Chen², Zhanchun Feng ${ }^{3}, X_{i}$ Chen $^{4}$, Zheng Wang ${ }^{5,6}$, Jianfeng Zhu ${ }^{7}$ Jun Jin ${ }^{8}$, Qiang Yao ${ }^{9}$, Li Xiang ${ }^{3}$, Lan Yao ${ }^{3,10}$, Ju Sun ${ }^{9}$, Lu Zhao ${ }^{11}$, Hong Fung ${ }^{12}$, Eliza Lai-yi Wong ${ }^{12}$ and Dong Dong ${ }^{12^{*}}$ (D)

\begin{abstract}
Background: More than $90 \%$ of the Chinese population was covered by its three basic social health insurances. However, the Chinese rural-to-urban migrant workers (RUMWs), accounting for about one-fifth of China's total population, seem to be put on a disadvantaged position under the current health insurance schemes. The purpose of this study is to identify the current barriers and to provide policy suggestions to the ineffective health insurance coverage of RUMWs in China.

Methods: A systematic review guided by the Preferred Reporting Items for Systematic Reviews and Meta-Analysis (PRISMA) guidelines. The searched databases included PubMed, Embase, Medline, Web of Science, PsycINFO, Maternity and Infant Care Database MIDIRS, the Cochrane Library, WHO Library Database (WHOLIS), WHO Global Health Library, World Bank eLibrary, OpenGrey, CNKI, and Wanfang. In total, 70 articles were reviewed.

Results: (1) Chinese RUMWs have high work mobility and low job stability; (2) Barriers faced by RUMWs in obtaining effective health insurance coverage are primarily due to the reluctance of employers to provide insurance for all employees and the disadvantaged position held by RUMWs when negotiating with their employers; (3) Fissures among existing health insurance schemes leaves no room for RUMWs to meet their primary needs; and (4) Recent efforts in improving the portability and transferability of insurance across borders and schemes are not enough to solve the barriers.

Conclusion: It is argued that the Chinese central government must deal with the fragmentation of healthcare system in China and promote effective coverage by: (1) playing a more active role in coordinating different healthcare and social welfare schemes across the country, (2) increasing the health insurance portability, (3) making the healthcare policies more compatible with RUMW's characteristics to meet their primary health needs, (4) strengthening supervision of employers, and (5) providing more vocational training and other support to increase RUMW's job stability.
\end{abstract}

Keywords: China, Rural-to-urban migrant workers, Universal health coverage, Systematic review

\footnotetext{
* Correspondence: dongdong@cuhk.edu.hk

${ }^{12}$ The Jockey Club School of Public Health and Primary Care, Faculty of Medicine, The Chinese University of Hong Kong, Hong Kong SAR, China Full list of author information is available at the end of the article
}

(c) The Author(s). 2020 Open Access This article is licensed under a Creative Commons Attribution 4.0 International License, which permits use, sharing, adaptation, distribution and reproduction in any medium or format, as long as you give appropriate credit to the original author(s) and the source, provide a link to the Creative Commons licence, and indicate if changes were made. The images or other third party material in this article are included in the article's Creative Commons licence, unless indicated otherwise in a credit line to the material. If material is not included in the article's Creative Commons licence and your intended use is not permitted by statutory regulation or exceeds the permitted use, you will need to obtain permission directly from the copyright holder. To view a copy of this licence, visit http://creativecommons.org/licenses/by/4.0/ The Creative Commons Public Domain Dedication waiver (http://creativecommons.org/publicdomain/zero/1.0/) applies to the data made available in this article, unless otherwise stated in a credit line to the data. 


\section{Background}

Universal health coverage (UHC) is a vision where all people and communities have access to quality healthcare services where and when they need them, without suffering financial hardship [1,2]. The concept of UHC is in line with China's health reform launched in 2009, which announced a provision of affordable and equitable basic health care for all by 2020 [3]. In October 2016, another ambitious plan-healthy China 2030-advances the concept of UHC in China from pursuing widespread coverage to effective coverage [4].

As early as 2010, more than $90 \%$ of the Chinese population was covered by its three basic social health insurances (SHI) [5], namely New-rural Cooperative Medical Scheme (NCMS) for rural residents, Urban Residentbased Basic Medical Insurance (URBMI) for urban residents, and Urban Employee-based Basic Medical Insurance (UEBMI) for formal urban workers) [6]. Their role in increasing health service accessibility, reducing economic burden, and improving health equity are evidential $[5,7]$.

However, the studies during 2014 and 2018 indicated that the Chinese rural-to-urban migrant workers (RUMWs) - villagers who migrate to urban areas for employment opportunities-seem to be put on a disadvantaged position in UHC. Their effective health insurance coverage is low [8-13], largely because they are geographically removed from their place of insurance registration. Meanwhile the insurance provided by their workplace is often insufficient or even absent. Consequently, it is not uncommon for RUMWs to use no treatment [14-20], self-treatment [15-22] or informal health services $[14-16,19,23-25]$ when they are sick. The problem of geographical disjunction from the health insurance register and usage makes health services less accessible for RUMWs [14, 16, 19-21, 23, 26-32] or they have to face higher health economic burden compared with urban or even rural residents $[9,11,14-16$, 21, 23, 33-35].

Eliminating this geographical disjunction in access to health insurance has been the primary goal of the creation and revision of health policies related to RUMWs by two Chinese government policies, issued in 2010 [36] and 2016 [37] respectively. However, studies have shown that, even though RUMWs live in urban areas, they are still greatly marginalized by the urban health system $[8$, $12,26,38-40]$. The percentage of RUMWs covered by health insurance in their flow-in areas has fluctuated between 18 and 20\% since 2008 [41]. This low effective coverage and fluctuating percentage is frequently attributed to the defect in the design of China's health insurance system.

RUMWS usually take jobs shunned by urbanites and contribute significantly to urban development [14, 38].
By 2017, there were 286.5 million RUMWs, accounting for about one-fifth of China's total population [41]. The huge population of RUMWs directly influences the achievement of UHC or the effectiveness of UHC in China. Therefore, to facilitate better implementation of the UHC on RUMWs, a systematic review was conducted. Primarily focusing on the effectiveness of health insurance coverage, our review is composed of five parts: 1) the characteristics of RUMWs and the features of their health needs, 2) the barriers faced by RUMWs in obtaining effective health insurance coverage, 3) the policy gaps in existing efforts to solve the barriers, and 4) domestic and international innovative approaches that can be helpful in improving the effective health insurance coverage for RUMWs. In the final section, we propose potential strategies on how to overcome the current barriers and make changes to the ineffective health insurance coverage of RUMWs in China.

\section{Methods ${ }^{1}$}

The aim of the study is three-fold: (1) to review China's healthcare policies and their applications to rural-tourban migrant workers (RUMWs) in China; (2) to identify problems faced by RUMWs and the policy gaps that need to be addressed in future; and (3) to facilitate better implementation of the UHC on RUMWs.

\section{Search strategy}

For the systematic review, we used the steps recommended in the Preferred Reporting Items for Systematic Reviews and Meta-Analysis (PRISMA) guidelines. We searched PubMed, Embase, Medline, Web of Science, PsycINFO, Maternity and Infant Care Database MIDIRS, the Cochrane Library, WHO Library Database (WHOLIS), WHO Global Health Library, World Bank eLibrary, OpenGrey, CNKI (zhiwang, 知网, a major Chinese academic publication consolidation database), and Wanfang (万方, another major Chinese academic database) for published or unpublished papers and reports in English or Chinese between Jan 1, 2008, and Dec 31, 2018. We searched for studies published after Jan 1, 2008, because the situation in China has been changing rapidly, and the information provided by older studies may already be detached from their original research contexts and be less useful for further work. The research strategy was developed based on similar reviews in other settings [42-45]. The search terms used controlled vocabulary and free text, which included word combinations intended to capture a variety of Chinese and English

\footnotetext{
${ }^{1}$ Development of search strategy and selection criteria, study selection, quality assessment, as well as data extraction were conducted independently by two authors (SC, QY), with discussions with a third author (LX) until a consensus was reached in the case of discrepancies. The detailed process can be found in supplement s1.
} 
texts depicting Nongmingong (农民工, in Chinese, literally meaning peasant worker) and rural-to-urban migrants (in English, e.g., Migra* or Transient* or Emigra* Peasant" or Newcom" or New-com" or "Mobil" population" or "Mobil" people" or "Mobil" work" or "Float" population" or "Float" people" or "Float" work").

\section{Inclusion and exclusion criteria}

The inclusion and exclusion criteria are primary twofold. First, we included studies that offer the information related to accessibility, acceptability, affordability, and availability in the view of RUMWs [46-48] and "six building blocks" in the view of health system [49] - service delivery, health workforce, health information systems, access to essential medicines, financing and leadership/governance. Second, only original research was included; comments, correspondence, and editorials were excluded.

\section{Quality assessment}

Quality assessment was conducted as follows: The quality of the observational cohort/cross-sectional studies and case-control studies was assessed using an adaptation of Study Quality Assessment Tools (SQAT) developed by the US National Institutes of Health (NIH) [50]. The quality of the qualitative studies was assessed using an adaptation of the Critical Appraisal Skills Programme (CASP) quality-assessment tool [51]. Each of the quantitative findings was assessed using the GRADE (Grading of Recommendations Assessment, Development, and Evaluation) approach [52], and each of the qualitative findings was assessed using the GRADE-CERQual (Confidence in the Evidence from Reviews of Qualitative Research) approach [53].

The detailed process can be found in supplement s1.

\section{Results}

Through our searches, 70,687 records were identified from the English database, and 15,220 records were identified from the Chinese database. After removing 29, 224 duplicated records, 56,683 records were screened, of which 279 full-text articles were assessed for eligibility, and 70 articles that fit the standards were included in this study (Fig. 1).

\section{Characteristics of RUMWs and features of their health needs}

RUMWS have long been considered a vulnerable group due to their poor education [14, 21, 26, 40], poor living conditions [14, 15], long working hours [14, 21, 40], and low income $[14,40]$. They lack social integration in the city $[14,15,34,54]$, and mainly rely on their kinship and friendships for social support [14, 34]. More than half of them move across provinces (27.2\%) or across cities
(32.9\%) when they are young [55], but inevitably return to their hometown when they are too aged or ill to support their floating life [40]. They usually do not have special skills, and typically take temporary work in private sectors because state sectors usually reserve jobs for locals or skilled workers [14, 19, 40, 56, 57]. A majority of RUMWs are discriminated and treated as a low-cost labor force. But sometimes they are also acclaimed as contributors to urbanization and economic development $[14,16,17,28,33,38,58]$. Therefore, most RUMWs have high work mobility and low job stability, placing them in a disadvantaged and marginalized socioeconomic position [33].

The inherent characteristics of RUMWs inevitably shape their health needs, as follows: (1) They exhibit better physical health $[17,19,40,59,60]$, but worse mental health than local residents $[17,19,34,59,2)$ Except for industrial injury, they are less likely to suffer from serious diseases, but are more likely affected by common ailments, infectious diseases [15, 60-62] or sexually transmitted diseases $[3,63]$ Their needs for healthcare and medical services are often delayed and the origins of their illness are often far from where they end up [14, 34], as they devote their young and healthy bodies to the flow-in cities, and bring their older and ailing bodies back to the flow-out place [40]. The question is: What factors contribute to the suffering of RUMWs in China within the current healthcare system? Through a review of existing literature, we have identified two major barriers.

\section{Barriers to effective health insurance coverage among RUMWs}

Barrier 1: difficulties of RUMWS being included in the healthcare system in the flow-in areas

Due to historical reasons, the Chinese welfare system is mainly financed at the local level [38, 64]. However, for local governments, even today, the local GDP growth rate is one of the most important political performance indicators [38]. Therefore, local governments are caught in a dilemma. On one hand, they need to expand welfare coverage to attract skilled migrants to contribute to local economic growth, but this raises the labor costs and increases local finance burdens [38]. On the other hand, they are reluctant to bear excessive financial burden because they need to control labor costs to attract investment funds [38]. To compromise effectively, the local government expanded the welfare coverage to the RUMWs with the desired skills and qualifications [33, 38, 64].

Business sectors face a dilemma similar to the local governments [65]. Since both the employee and the employer need to contribute to the employee's welfare account, the high work mobility and low job stability of RUMWs could increase the burden for the employers [38]. Further, the Labor Contract Law bundles the health 


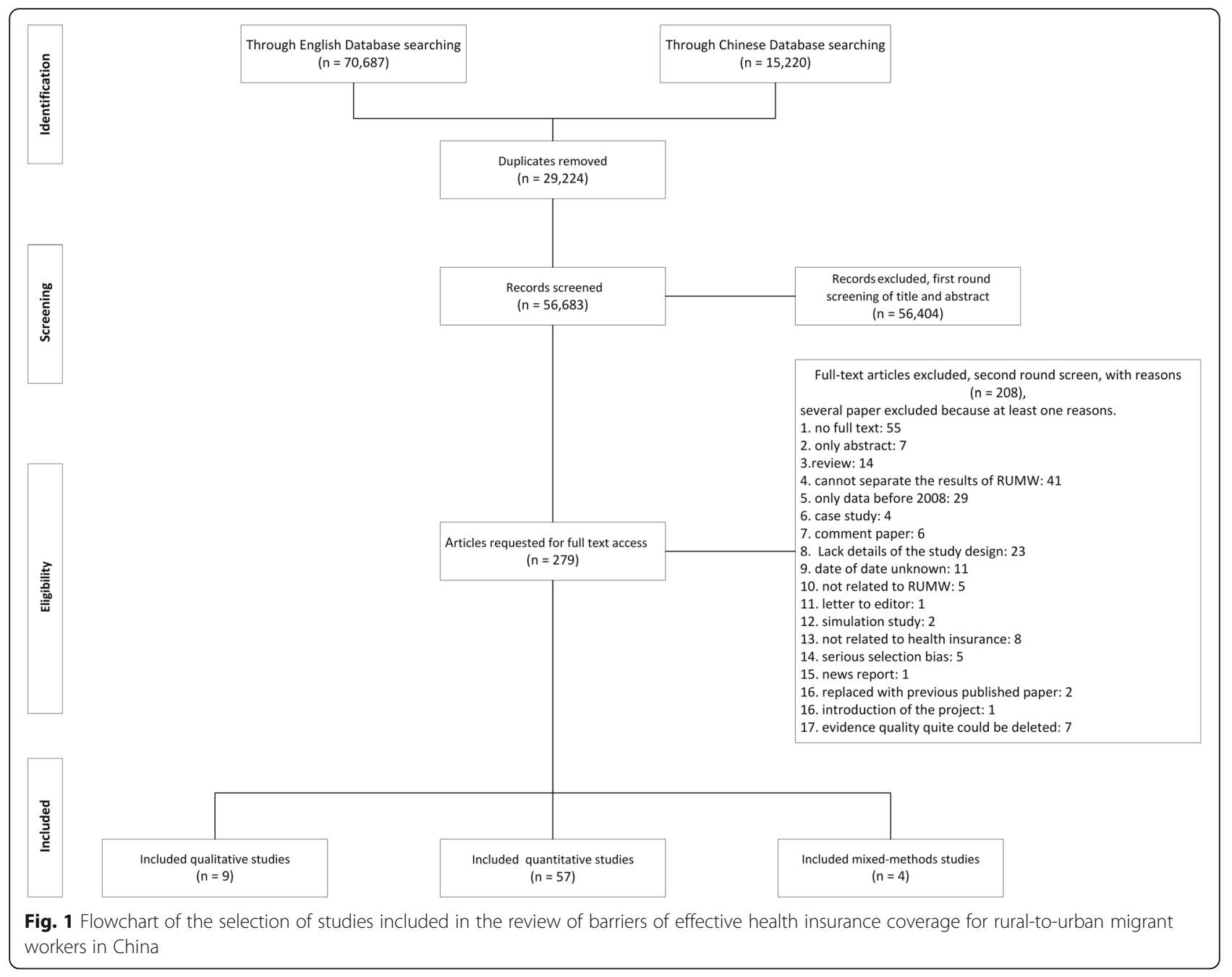

insurance premium with other welfare programs, such as pension insurance, unemployment insurance, onthe-job injury insurance, maternity insurance, and housing provident fund [38, 58, 65-67]. This bundling leads to an increased burden for local governments and business sectors $[38,65]$. As a result, the business sectors-especially private enterprises [64, 67] and small and medium-sized enterprises (SMEs) [68] have adopted a similar strategy trying to avoid providing insurance coverage to all RUMWs $[64,65,69$, 70].

The local governments have now developed greater financial capacities to accommodate people that they had excluded before, but due to a lack assistance from government or nongovernment organizations $[15,28,57]$ coupled with their disadvantaged and marginalized socioeconomic status, RUMWs remain in a weak position during negotiations with their employers $[8,64,69]$. Even when RUMWs sign a formal contract with their employers, they are sometimes hired by subcontractors or labor dispatch companies, and thus their labor relationship with their true employers are not clear and cannot be fully protected by the Labour Contract Law [14, 15, 57, 67]. Similarly, in cases where the employers refuse to pay premium for RUMWs [26, 65], the employer's accountability is not supervised or well-regulated [15, 26, 67].

Barrier 2: fissures among existing health insurance schemes leaves no room for RUMWs to meet their primary needs

The evidence generated during 2013 and 2018 indicated that due to the fragmentation of its healthcare system $[15,38,69,70]$, health insurance portability or transfer in China is low [38, 64, 71-74]. More recently, there have been reforms in both the healthcare and social security sectors, which lead toward the integration of NCMS and URBMI [75, 76]. Through this, the fragmentation of China's health system 
should be greatly reduced. Yet the fissures between NCMS and URBMI or UEBMI still exist. Specific barriers that hinder the portability of health insurance are elaborated below (summary in Table 1).

\section{Low portability between URBMI and NCMS for} RUMWs. "Health insurance portability" means that an insurance holder can transfer his/her insurance from one plan to another plan, and from one place to another place $[73,80]$. As the World Bank report of "The Path to Integrated Insurance Systems in China" [81] suggests, the integration of NCMS and URBMI will increase the portability of both NCMS and URBMI.

However, both insurances are registered based on the unit of family, while most RUMWs migrate to cities without their families $[57,65]$.

Participating in URBMI in the flow-in place will leave their families uninsured. Whereas the leftbehind elderly family members are often the primary users of NCMS in the flow-out place [65]. This dilemma leaves the RUMWs no choice but to keep NCMS for their families and leave themselves uninsured.

2. Incompatibility between UEBMI and NCMS for RUMWs. Both UEBMI and NCMS have a risksharing account, and UEBMI also has an individual account funded by the employees such as the RUMWs. The risk-sharing account for UEBMI is funded by the employers, while the one for NCMS is funded by both the government and the family. Contributions from the employers and the local governments have a strong and direct influence on the affordability and sustainability of the local social welfare system. Therefore, by no means are the local governments willing to transfer out the funds in the risk-sharing accounts of UEBMI or the funds paid by the government in NCMS $[71,80]$. Currently, only the funds in the individual account of UEBMI and the funds contributed by the family in NCMS [71, 80] are portable. Moreover, even if the RUMWs are allowed to transfer from NCMS to UEBMI, they are less likely to do so due to the economic burden induced by the high premiums for UEBMI $[14,38,68,69,82]$.

3. Including RUMWs into the migrant work health insurance (MWHI). MWHI is a plan specifically designed to solve the health needs of the increasing number of migrant workers. Despite the variance of MWHI across regions, the evidence generated during 2009 and 2010 indicated that almost all MWHIs are featured by low premium, mandatory employer contribution, and inpatient first $[14,83]$. MWHI considers the low income of RUMWs, but it is still a voluntary program and only effective after signing a formal labor contract. Therefore, as outlined in Barrier 1 , issues such as reluctance of the employers to offer health insurance for RUMWs also applies to MWHI. Additionally, two studies from 2010 and 2013 indicated that only offering risk protection for inpatient services is essentially a mismatch with the health needs of RUMWs [70, 84]. Two studies from 2013 and 2015 indicated that MWHI has almost zero portability, which is also incompatible with the RUMWs' high place mobility and low job stability [70, 77].

4. Keeping the RUMWs covered by the NCMS in their flow-out place. In fact, this is the option chosen by most RUMWs [19, 26, 85-87]. About $60 \%$ of RUMWs stay in the NCMS in their flowout place, as shown in Table 1. However, the use of NCMS is largely bounded by geography. With the development of NCMS, it has become normal for NCMS to cover services beyond their municipal or provincial boundaries. However, most of the evidence updated to 2018 indicated that only hospital services are reimbursed through NCMS across borders and no primary health services are included $[88,89]$. Thus, the fundamental health needs of RUMWs cannot be met by this mechanism.

Policy gaps in existing solutions to increase effective health insurance coverage of RUMWs

Two new reforms are linked to the benefits of RUMW: the implementation of Interim Measures for the Transfer and Continuation of Basic Medical Security Relationships of Migrant Employees (launched in 2010 and modified in 2016, 36, 37] and the integration of WMHI into UEBMI. However, both solutions have problems that prevent the RUMWs being effectively covered by health insurance.

\section{Policy gap 1: lacking detailed policies has exacerbated fragmentation and is not helpful for health insurance portability}

The Interim Measures is a national level solution to the geographical exclusion caused by mobile employment, which allows insurance transfers between regions or between plans. It is an important policy for achieving effective coverage of the Chinese UHC. In the 2010 version of the Interim Measures [36], the stipulations related to RUMWs are: 1) no double coverage by the three basic SHI (i.e., NCMS, URBMI, and UEBMI); 2) the government flow-in area cannot refuse the migrant worker from taking part in the 
Table 1 Comparison of health insurance currently available for rural-to-urban migrant workers

\begin{tabular}{|c|c|c|c|c|}
\hline & NCMS & URBMI & UEBMI & Early MWHI \\
\hline Launch year & 2003 & 2007 & 1998 & 2006 \\
\hline \multicolumn{5}{|l|}{ Eligible conditions } \\
\hline Eligible population & $\begin{array}{l}\text { Rural, employed/non- } \\
\text { employed }\end{array}$ & $\begin{array}{l}\text { Urban, non- } \\
\text { employed }\end{array}$ & $\begin{array}{l}\text { Urban/rural, employed/self- } \\
\text { employed }\end{array}$ & $\begin{array}{l}\text { rural in urban, } \\
\text { employed }\end{array}$ \\
\hline contract & - & - & Necessary & Necessary \\
\hline Dependence on employee & - & - & Yes & Yes \\
\hline \multicolumn{5}{|l|}{ Coverage rate $^{a}$} \\
\hline In flow-out area & $57.6 \%+3.5 \%$ & $3.4 \%+3.5 \%$ & $3.0 \%$ & $<0.7 \%$ \\
\hline In flow-in area & $6.7 \%+1.4 \%$ & $3.7 \%+1.4 \%$ & $18.6 \%$ & $<1.5 \%$ \\
\hline Total & $64.7 \%+4.9 \%$ & $7.2 \%+4.9 \%$ & $21.9 \%$ & $<2.2 \%$ \\
\hline Insurance type ${ }^{b}$ & $\begin{array}{l}\text { Limited-duration } \\
\text { health insurance }\end{array}$ & $\begin{array}{l}\text { Limited-duration } \\
\text { health insurance }\end{array}$ & $\begin{array}{l}\text { Limited-payment whole-life } \\
\text { health insurance }\end{array}$ & $\begin{array}{l}\text { Limited-duration } \\
\text { health insurance }\end{array}$ \\
\hline Guarantee period & The following one year & $\begin{array}{l}\text { The following one } \\
\text { year }\end{array}$ & $\begin{array}{l}\text { The following one year and } \\
\text { future }\end{array}$ & $\begin{array}{l}\text { The following one } \\
\text { year }\end{array}$ \\
\hline Account type & Risk-sharing account & Risk-sharing account & $\begin{array}{l}\text { Individual account + risk-sharing } \\
\text { account }\end{array}$ & Risk-sharing account \\
\hline
\end{tabular}

\section{Financing strategy [6]}

Minimum financing unit

Financing contribution rate

Total financing amount per unit (RMB/ year)

Bundled with other welfare programs

Employer's total contribution rate [38]

Employee or individual's total contribution rate [38]

Total amount of burden for funders per unit (RMB/year/people) ${ }^{c}$

\section{Covered services}

Matching with RUMWs' health need

Geographic consistency for RUMWs

Portability, in the view of RUMWs $[64,70,73,77]$

Membership selectivity $[38,64,71]$

\section{Family: 20\% \\ Government subsidy: $80 \%$}

NA

NA

-
-
Family: 220
Government subsidy:
490

flow-out area: Outpatient + Inpatient flow-in area: Inpatient

\section{Mismatch \\ geographically separated}

Low
Family

Family: $30 \%$
Government subsidy:
$70 \%$

NA

NA

Family: 220

Government subsidy: 490

Outpatient + Inpatient

Match

geographically consistent

Low
Employed: employee + employer Self-employed: individual

$8 \%$ of payroll

Employed:

employee: $2 \%$

employer: 6\%

Self-employed: 8\%

$3485 * 12 * 8 \%=3345.6$

Pension insurance

On-the-job injury insurance

Unemployment insurance

Maternity insurance

Urban Minimum Standard Living

Allowance Program

Housing provident fund

Approximately 30\%

Employed: Approximately

10\%Self-employed: $8 \%$

Employed:

employee: $3485 * 12 * 10 \%=$

4182

employer: $3485 * 12 * 30 \%=12$,

546

Self-employed: $3485 * 12 * 8 \%=$ 3345.6

Outpatient + Inpatient

Match

geographically consistent

Quite low
Low

Inpatient

Mismatch

geographically consistent

ployed: employee or + employer Self-employed: individual

Low

Low

Yes or no

Low

Low

No 
Table 1 Comparison of health insurance currently available for rural-to-urban migrant workers (Continued)

\begin{tabular}{lllll}
\hline & NCMS & URBMI & UEBMI & Early MWHI \\
\hline Employee & - & - & High & Low \\
Government & Low & Low & High & - \\
\hline
\end{tabular}

${ }^{a}$ The percentage is calculated from China Migrants Dynamic Survey, a national survey covering about 78 thousand RUMWs [78]. Several places integrated NCMS and URBMI in to one. The percentage after the plus sign is of those who took part in the integrated NCMS and URBMI

${ }^{\mathrm{b}}$ Limited-payment whole-life health insurance refers to the insurance plan that has a set period, in which an insurance holder pay premiums into the policy. Once the holder reaches the target years, premiums are no longer required but the policy's benefits lasts the insured's entire life. Limited-duration health insurance refers to a plan with a limited duration, paid by years or less

c " 220 " is drawn from the payment standards for basic medical insurance of urban and rural residents in 2018 [79]; "3458" from the average payroll of RUMWs in 2017 [41]

local SHI using the excuse of hukou ${ }^{2}$; 3) the RUMW, who has a stable labor relationship with a local institution, should be covered by local UEBMI; 4) the RUMW, who has an unstable labor relationship with a local institution, can voluntarily chose to keep their insurance in the flow-out place or to utilize the local basic health insurance; and 5) when the RUMWs return and if they still hold the rural hukou, they need to re-transfer their insurance back to the NCMS in their hometown.

However, none of these five stipulations consider the dilemmas faced by RUMWs illustrated above. The fifth stipulation can even cause loss in benefits to the RUMWs if they are covered by the UEBMI in their flow-in place. In addition, a lack of details in the Interim Measures has exacerbated the fragmentation among local policies since different regions have developed their own operational approaches for the SHI relationship transfer [71]. Studies also show that the transfer of health insurance for migrant workers does not work well $[74,80]$, especially for those who have high mobility $[70,90,91]$. Finally, what is noteworthy is that the ideas behind second and fifth stipulation are against with each other. The former one tries to weaken the influence of hukou, while the later one actually strengthens it.

In 2016, the Interim Measures were modified [37]. The newer version deletes the above five stipulations and seems to increase the mutual portability among three SHI. But how to understand and implement the Interim Measures almost completely depend on the local government. Due to the lack implementation details, local governments who have already formed their own rules are less like to revise or make the implementation more effectively [38]. More critically, the same as the 2010 version, the 2016 version does not touch the risk-sharing accounts that are highly related to the benefits of the local government. Problems elaborated in Barrier 2 are not tackled and the RUMWs' primary health needs are not dealt with.

\footnotetext{
${ }^{2}$ The hukou system in china was established in the 1950s. It split people into different type (agricultural vs. non-agricultural) and location (rural vs. urban in different administrative areas), and laid the foundation of institutional pillar.
}

Another problem for current policies is the ambiguous description of eligibility. For most policies, the eligibility of local health insurance for the RUMWs is based on stable labor relations. However, what the stable means is not clear $[38,83]$. This also gives the employer a chance to evade their responsibility, if they recruit workers from subcontractors or labor dispatch companies [14, 15, 57]. An additional question is which insurance self-employed RUMWs are eligible for, WMHI, UEBMI, or URBM? The related description about them are usually absent $[14,70$, 83]. For instance, in Table 2, we will introduce next, none of Beijing, Shanghai and Shenzhen gave a clear statement.

\section{Policy gap 2: forced integration of two very different insurance plans may worsen the exclusion of RUMWs}

The MWHI is specially designed for migrant workers. However, it has exacerbated the fragmentation of Chinese insurance system. In the trend of integration, some regions have begun to discard the migrant insurance, and integrate it into UEBMI or merge it with other health insurances. Table 2 compares before and after the reform of MWHI in Beijing [97-99], shanghai [92-96], and Shenzhen [100102]. MWHI is similar with NCMS in the view of insurance type, hence the difference between MWHI and UEBMI is significant, and previous comparison between NCMS and UEBMI also suit to MWHI and UEBMI. Integrated MWHI into UEBMI means a higher costs to RUMWs themselves, government and enterprises, and the selectivity motivation of government and enterprises is higher in via of UEBMI than MWHI. Therefore, before solving of the conflicts of stakeholders' interests as well as the problems faced by RUMWs, it can be speculated that the forced integration will worsen the exclusion of RUMWs from the urban insurance system, especially for those who are treated as unskilled workers.

\section{Domestic and international innovative approaches to improve the effective health insurance coverage for RUMWs}

Domestic innovation cases

Among MWHIs in China, the model used in Shanghai and Shenzhen are considered positive examples [8]. 
Table 2 comparison of before and after the reform on MWHI in Beijing, shanghai and Shenzhen

\begin{tabular}{|c|c|c|c|c|c|c|c|c|}
\hline & \multicolumn{2}{|l|}{ Shangha i[92-96] } & \multicolumn{2}{|c|}{ Beijin g[97-99] } & \multicolumn{4}{|c|}{ Shenzhe n[100-102] } \\
\hline & \multirow[t]{2}{*}{ Before 2011} & \multirow[t]{2}{*}{ After 2011} & \multirow[t]{2}{*}{ Before 2012} & \multirow[t]{2}{*}{ After 2012} & \multirow[t]{2}{*}{ Before 2014} & \multicolumn{3}{|l|}{ After 2014} \\
\hline & & & & & & Category I & Category II & $\begin{array}{l}\text { Category } \\
\text { III }\end{array}$ \\
\hline \multicolumn{9}{|l|}{ Eligible conditions } \\
\hline Eligible population & Non-local workers & $\begin{array}{l}\text { Local/non-local } \\
\text { workers }\end{array}$ & $\begin{array}{l}\text { Non-local } \\
\text { workers }\end{array}$ & $\begin{array}{l}\text { Local/non-local } \\
\text { workers }\end{array}$ & $\begin{array}{l}\text { Non-local } \\
\text { workers }\end{array}$ & $\begin{array}{l}\text { Local/non- } \\
\text { local workers }\end{array}$ & \multicolumn{2}{|c|}{ Non-local workers } \\
\hline Contract & Unnecessary & Necessary & Necessary & Necessary & Necessary & \multicolumn{3}{|l|}{ Necessary } \\
\hline $\begin{array}{l}\text { Dependence on } \\
\text { employee }\end{array}$ & No & Yes & Yes & Yes & Yes & \multicolumn{3}{|l|}{ Yes } \\
\hline Insurance type ${ }^{a}$ & $\begin{array}{l}\text { Limited-duration } \\
\text { health insurance }\end{array}$ & $\begin{array}{l}\text { Limited- } \\
\text { payment } \\
\text { whole-life } \\
\text { health } \\
\text { insurance }\end{array}$ & $\begin{array}{l}\text { Limited- } \\
\text { duration } \\
\text { health } \\
\text { insurance }\end{array}$ & $\begin{array}{l}\text { Limited- } \\
\text { payment } \\
\text { whole-life } \\
\text { health } \\
\text { insurance }\end{array}$ & $\begin{array}{l}\text { Limited- } \\
\text { duration } \\
\text { health } \\
\text { insurance }\end{array}$ & \multicolumn{3}{|c|}{$\begin{array}{l}\text { Limited-payment whole-life health } \\
\text { insurance }\end{array}$} \\
\hline Guarantee period & $\begin{array}{l}\text { The following one } \\
\text { year }\end{array}$ & $\begin{array}{l}\text { The following } \\
\text { one year and } \\
\text { future }\end{array}$ & $\begin{array}{l}\text { The } \\
\text { following } \\
\text { one year }\end{array}$ & $\begin{array}{l}\text { The following } \\
\text { one year and } \\
\text { future }\end{array}$ & $\begin{array}{l}\text { The } \\
\text { following } \\
\text { one year }\end{array}$ & \multicolumn{3}{|c|}{ The following one year and future } \\
\hline Account type & $\begin{array}{l}\text { Individual account } \\
+ \text { risk-sharing } \\
\text { account }\end{array}$ & $\begin{array}{l}\text { Individual } \\
\text { account + risk- } \\
\text { sharing account }\end{array}$ & $\begin{array}{l}\text { Risk-sharing } \\
\text { account }\end{array}$ & $\begin{array}{l}\text { Individual } \\
\text { account + risk- } \\
\text { sharing account }\end{array}$ & $\begin{array}{l}\text { Risk-sharing } \\
\text { account }\end{array}$ & $\begin{array}{l}\text { Individual } \\
\text { account + risk- } \\
\text { sharing } \\
\text { account }\end{array}$ & \multicolumn{2}{|c|}{ Risk-sharing account } \\
\hline $\begin{array}{l}\text { Management } \\
\text { agency }\end{array}$ & $\begin{array}{l}\text { Commercial } \\
\text { insurance } \\
\text { company }\end{array}$ & $\begin{array}{l}\text { Social insurance } \\
\text { agency }\end{array}$ & $\begin{array}{l}\text { Social } \\
\text { insurance } \\
\text { agency }\end{array}$ & $\begin{array}{l}\text { Social insurance } \\
\text { agency }\end{array}$ & $\begin{array}{l}\text { Social } \\
\text { insurance } \\
\text { agency }\end{array}$ & \multicolumn{3}{|c|}{ Social insurance agency } \\
\hline \multicolumn{9}{|l|}{ Financing strategy } \\
\hline $\begin{array}{l}\text { Minimum } \\
\text { financing unit }\end{array}$ & $\begin{array}{l}\text { Employed: } \\
\text { employee } \\
\text { Self-employed: } \\
\text { individual }\end{array}$ & $\begin{array}{l}\text { Employed: } \\
\text { employee + } \\
\text { employer }\end{array}$ & Employer & $\begin{array}{l}\text { Employee + } \\
\text { employer }\end{array}$ & $\begin{array}{l}\text { Employee + } \\
\text { employer }\end{array}$ & \multicolumn{3}{|c|}{ Employee + employer } \\
\hline $\begin{array}{l}\text { Financing } \\
\text { contribute rate }\end{array}$ & $\begin{array}{l}12.5 \% \text { (non-local } \\
\text { construction } \\
\text { enterprise rate is } \\
5.5 \% \text { ) }\end{array}$ & $\begin{array}{l}\text { Employee: } 9.5 \% \\
\text { Employer: } 2 \%\end{array}$ & $\begin{array}{l}\text { Employer: } \\
2 \%\end{array}$ & $\begin{array}{l}\text { Employee } 2 \%+ \\
3 \text { RMB } \\
\text { Employer: } 10 \%\end{array}$ & $\begin{array}{l}\text { Employee: } 4 \\
\text { RMB/month } \\
\text { Employer: } 8 \\
\text { RMB/month }\end{array}$ & $\begin{array}{l}\text { Employee } 2 \% \\
\text { Employer: } \\
5.2 \% \text { or } 6.2 \%\end{array}$ & $\begin{array}{l}\text { Employee } \\
0.2 \% \\
\text { Employer: } \\
0.6 \%\end{array}$ & $\begin{array}{l}\text { Employee } \\
0.1 \% \\
\text { Employer: } \\
0.45 \%\end{array}$ \\
\hline $\begin{array}{l}\text { Total financing } \\
\text { amount per unit } \\
\text { (RMB/year) }\end{array}$ & $\begin{array}{l}3485 * 12 * 12.5 \% \\
\text { or } 5.5 \%\end{array}$ & $\begin{array}{l}3485^{*} 12^{*} \\
11.5 \%\end{array}$ & $\begin{array}{l}3485 * 12 * \\
2 \%\end{array}$ & $\begin{array}{l}3485 * 12 * \\
12 \%+36\end{array}$ & $12^{*} 12$ & $\begin{array}{l}3485 * 12 * \\
7.2 \% \text { or } 8.2 \%\end{array}$ & $\begin{array}{l}3485 * 12 * \\
0.8 \%\end{array}$ & $\begin{array}{l}3485 * 12 * \\
0.55 \%\end{array}$ \\
\hline $\begin{array}{l}\text { Bundled with } \\
\text { other welfare } \\
\text { programs }\end{array}$ & $\begin{array}{l}\text { Pension insurance } \\
\text { On-the-job injury } \\
\text { insurance }\end{array}$ & $\begin{array}{l}\text { Same with } \\
\text { UEBMI }\end{array}$ & NA & $\begin{array}{l}\text { Same with } \\
\text { UEBMI }\end{array}$ & NA & \multicolumn{3}{|c|}{ Same with UEBMI } \\
\hline $\begin{array}{l}\text { Employer's total } \\
\text { contribution rate }\end{array}$ & $\begin{array}{l}12.5 \% \text { (non-local } \\
\text { construction } \\
\text { enterprise rate is } \\
5.5 \% \text { ) }\end{array}$ & $31.2-32.9 \%$ & $2 \%$ & $30.8-32.5 \%$ & $8 * 12 \mathrm{RMB}$ & $18.49-20.49 \%$ & $\begin{array}{l}15.16- \\
16.16 \%\end{array}$ & $\begin{array}{l}14.74- \\
15.74 \%\end{array}$ \\
\hline $\begin{array}{l}\text { Employee or } \\
\text { individual's total } \\
\text { contribution rate }\end{array}$ & None & $10.50 \%$ & None & $10.2 \%+3 \mathrm{RMB}$ & 4 * $12 \mathrm{RMB}$ & $10.3 \%$ & $8.5 \%$ & $8.4 \%$ \\
\hline $\begin{array}{l}\text { Total amount of } \\
\text { burden by funders } \\
\text { per unit (RMB/ } \\
\text { year) }\end{array}$ & $\begin{array}{l}\text { Employed: } \\
\text { employee: None } \\
\text { employer: } 2300 \text { or } \\
5228 \\
\text { Self-employed: } \\
5228\end{array}$ & $\begin{array}{l}\text { Employed: } \\
\text { employee: } 4391 \\
\text { employer: 13, } \\
\text { 048-13,786 } \\
\text { Self-employed: } \\
\text { Unclear }\end{array}$ & $\begin{array}{l}\text { Employed: } \\
\text { employee: } \\
\text { None } \\
\text { employer: } \\
836 \\
\text { Self- } \\
\text { employed: } \\
\text { Unclear }\end{array}$ & $\begin{array}{l}\text { Employed: } \\
\text { employee: } 4320 \\
\text { employer: 12, } \\
881-13,592 \\
\text { Self-employed: } \\
\text { Unclear }\end{array}$ & $\begin{array}{l}\text { Employed: } \\
\text { employee: } \\
48 \\
\text { employer: } \\
96 \\
\text { Self- } \\
\text { employed: } \\
\text { Unclear }\end{array}$ & $\begin{array}{l}\text { Employed: } \\
\text { employee: } \\
4307 \\
\text { employer: } \\
7733-8569 \\
\text { Self-employed: } \\
\text { Unclear }\end{array}$ & $\begin{array}{l}\text { Employed: } \\
\text { employee: } \\
3555 \\
\text { employer: } \\
6340-6758 \\
\text { Self- } \\
\text { employed: } \\
\text { Unclear }\end{array}$ & $\begin{array}{l}\text { Employed: } \\
\text { employee: } \\
3513 \\
\text { employer: } \\
\text { 6464-6582 } \\
\text { Self- } \\
\text { employed: } \\
\text { Unclear }\end{array}$ \\
\hline Covered services & $\begin{array}{l}\text { Inpatient }+ \\
\text { commonly used } \\
\text { medicine }\end{array}$ & $\begin{array}{l}\text { Outpatient }+ \\
\text { Inpatient }\end{array}$ & Inpatient & $\begin{array}{l}\text { Outpatient }+ \\
\text { Inpatient }\end{array}$ & $\begin{array}{l}\text { Outpatient } \\
+ \text { Inpatient }\end{array}$ & \multicolumn{3}{|c|}{ Outpatient + Inpatient } \\
\hline Matching with & Mismatch & Match & Mismatch & Match & Match & \multicolumn{3}{|l|}{ Match } \\
\hline
\end{tabular}


Table 2 comparison of before and after the reform on MWHI in Beijing, shanghai and Shenzhen (Continued)

\begin{tabular}{|c|c|c|c|c|c|c|c|c|}
\hline & \multicolumn{2}{|c|}{ Shangha i[92-96] } & \multicolumn{2}{|c|}{ Beijin g[97-99] } & \multicolumn{4}{|c|}{ Shenzhe n[100-102] } \\
\hline & \multirow[t]{2}{*}{ Before 2011} & \multirow[t]{2}{*}{ After 2011} & \multirow[t]{2}{*}{ Before 2012} & \multirow[t]{2}{*}{ After 2012} & \multirow[t]{2}{*}{ Before 2014} & \multicolumn{3}{|l|}{ After 2014} \\
\hline & & & & & & Category I & Category II & $\begin{array}{l}\text { Category } \\
\text { III }\end{array}$ \\
\hline \multicolumn{9}{|l|}{$\begin{array}{l}\text { RUM's health } \\
\text { needs }\end{array}$} \\
\hline $\begin{array}{l}\text { Geographic } \\
\text { consistency }\end{array}$ & Consistent & Consistent & Consistent & Consistent & Consistent & Consistent & & \\
\hline $\begin{array}{l}\text { Portability, in the } \\
\text { view of RUMWs }[64, \\
70,73,77]\end{array}$ & No & Quite low & No & Quite low & No & Quite low & Low & Low \\
\hline \multicolumn{9}{|l|}{$\begin{array}{l}\text { Membership } \\
\text { selectivity }[38,64, \\
71]\end{array}$} \\
\hline Employee & Low & High & Low & High & Low & High & Moderate & Moderate \\
\hline Government & Low & High & Low & High & Low & High & Moderate & Moderate \\
\hline
\end{tabular}

${ }^{a}$ Limited-payment whole-life health insurance refers to the insurance plan that has a fixed period, in which an insurance holder pays premiums for the policy. Once the holder reaches the target years, premiums are no longer required but the policy's benefits last the insured's entire life. Limited-duration health insurance refers to the plan with a limited duration, paid by years or less

As shown in Table 2, Shanghai provided insurance coverage for RUMWs through its comprehensive insurance system before 2011. Though this model was replaced by UEBIMI in 2011, its biggest innovation was that it was based on commercial insurance. Researchers advocated that this model should be promoted as it can be well suited to RUMWs' high mobility and low stability because commercial insurance is not restricted by region $[8,83]$. However, based on our earlier review, unless the premium under this model is paid by RUMWs themselves or by the government in their flow-out place, the commercial model still does not provide a good solution to the extra-cost problem caused by RUMWs' high mobility and low stability faced by the government and enterprises in the flow-in place.

The innovation of the Shenzhen model lies in it combination of all health insurances into one after 2014, and in meeting different people's needs by providing optional packages. The advantages of this model are that: 1) it reduces the fragmentation between plans; 2) it overcomes the barrier of using the family as the minimum financing unit, and increases the portability of health insurance; 3) the optional packages are more compatible with the low incomes of RUMWs; 4) it covers outpatient services and meets the RUMWs' health needs; and 5) it is financed monthly and is more compatible with RUMWs' high mobility. However, there are some weaknesses: 1 ) it lacks details about the eligibility of the self-employed RUMW; and 2) similar to the Shanghai model, the extra-cost problem faced by the government and enterprises remains, caused by the RUMWs' high mobility and low stability.

\section{International experiences}

A few articles compared China's health system with those in other countries. Table 3 summarized what can be retrieved from approaches implemented in other countries or territories that face problems similar to China. In sum, in terms of migrant-workers' problems of insurance coverage or access to health services, countries who have a national health insurance are more likely to demonstrate the advantage of their system. Establishing a separate health insurance with low premiums for migrant workers is not an approach unique to China, but other countries consider in detail the migrant workers' characteristics, including low incomes and the need for more primary care. Based on the causes of the problems and the obstacles encountered in solving these problems, the European approach appears the most instructive for China.

Migrant workers are common in the EU [103, 104]. The biggest feature of the EU approach is that they consider the difference between countries; they steer clear of building one European system for all, but enhance the coordination among members from a legal level. The aim of regulations in the EU is to determine which national legislation applies to a migrant worker in all possible cases, and to avoid a situation where migrant workers are either insured in more than one Member State or not at all. The regulations have the following characteristics: 1) detailed explanations. For instance, article one of the regulations exhaustively enumerates and describes the definition of 27 related terms; 2) avoiding ambiguity. For instance, because of the situation, people may have business locally but not be employed locally. The definitions the regulation offer are "activity as an employed person" and "activity as a selfemployed person" rather than definitions of a "worker" or "self-employed person"; 3 ) only providing the principles and leaving space for the member states, but the 
Table 3 international approaches implementing in other countries or territory

\begin{tabular}{|c|c|c|c|}
\hline & USA & Kerala, India & Thailand \\
\hline Objectives & $\begin{array}{l}\text { Migratory and seasonal } \\
\text { agricultural workers } \\
\text { (MSAW) }\end{array}$ & Migrant workers & Migrant workers \\
\hline $\begin{array}{l}\text { Eligible } \\
\text { conditions }\end{array}$ & NA & $\begin{array}{l}\text { Has a work-related } \\
\text { proof }\end{array}$ & $\begin{array}{l}\text { Documented or } \\
\text { undocumented }\end{array}$ \\
\hline $\begin{array}{l}\text { What they } \\
\text { do. }\end{array}$ & $\begin{array}{l}\text { The federal Health } \\
\text { Resources and Services } \\
\text { Administration (HRSA), } \\
\text { through the Bureau of } \\
\text { Primary Health Care } \\
\text { (BPHC), administers } \\
\text { approximately } \$ 5.1 \text { billion } \\
\text { in federal grant support } \\
\text { to over } 1400 \text { community } \\
\text { health centers through } \\
10,000 \text { clinic sites in all } 50 \\
\text { states and territories }\end{array}$ & $\begin{array}{l}\text { Awaz Health Insurance } \\
\text { Scheme: provides } \\
\text { health insurance and } \\
\text { accidental death } \\
\text { coverage for migrant } \\
\text { workers living in the } \\
\text { state. }\end{array}$ & $\begin{array}{l}\text { 1. In } 2001 \text { the Tai Ministry } \\
\text { of Public Health set up } \\
\text { the migrant health } \\
\text { insurance scheme for all } \\
\text { migrants who are not } \\
\text { covered by social health } \\
\text { insurance.2. A second } \\
\text { strand of policy action on } \\
\text { migrant health was the } \\
\text { establishment by the } \\
\text { public health ministry in } \\
2003 \text { of innovative, } \\
\text { migrant-friendly services } \\
\text { with the aim of improv- } \\
\text { ing access to health care } \\
\text { for all migrants, whether } \\
\text { covered by insurance or } \\
\text { not. These included the } \\
\text { use of volunteer commu- } \\
\text { nity health workers, mo- } \\
\text { bile clinics for migrant } \\
\text { communities, bilingual } \\
\text { (mostly Tai and Burmese) } \\
\text { signposts and informa- } \\
\text { tion in health facilities, } \\
\text { and outreach services in } \\
\text { the workplace }\end{array}$ \\
\hline
\end{tabular}

\section{Is it a \\ separated \\ insurance? \\ Mandatory or voluntary \\ Who pays for - the eligibility}

$\begin{array}{ll}\text { Fee for the } & \text { Migrant Health Centers } \\ \text { services } & \text { receive funding under } \\ & \text { Section } 330(\mathrm{~g}) \text { of the } \\ & \text { Public Health Service Act } \\ & \text { and provides services } \\ & \text { regardless of their ability } \\ & \text { to pay. Individuals } \\ & \text { without health insurance } \\ & \text { will be able to pay for } \\ & \text { services based on a } \\ & \text { sliding-fee scale, and pay- } \\ & \text { ment is based on income } \\ & \text { and household size. } \\ \text { Management } & \text { National Association of } \\ \text { Community Health } & \text { Centers (NACHC) } \\ & \text { supports health centers } \\ & \text { caring for the MSAW } \\ & \text { population at both the } \\ & \text { program and policy } \\ & \text { levels. NACHC has a } \\ & \text { Committee on } \\ & \text { Agricultural Worker } \\ & \text { Health, which is }\end{array}$

Yes Yes

Voluntary

NA

Free with Awaz insurance card

Kerala Government

A specific hospital where they registered

Voluntary

$\begin{array}{ll}\text { Australia } & \text { European Union } \\ \begin{array}{l}\text { Seasonal migrant } \\ \text { workers }\end{array} & \begin{array}{l}\text { Migrant workers in the } \\ \text { EU }\end{array} \\ \text { - } & \text { NA } \\ & \\ \begin{array}{l}\text { 1. Medicare covers all } \\ \text { Australian citizens, } \\ \text { permanent residents and launching the } \\ \text { citizens of New Zealand } \\ \text { for free.2. External } \\ \text { migrant workers: Health } \\ \text { insurance is bundled } \\ \text { with Visa application }\end{array} & \begin{array}{l}\text { 2004, and Regulation } \\ \text { (E) No 987/2009 of the } \\ \text { of the Council, } \\ \text { coordinates the social } \\ \text { security systems between } \\ \text { European members from }\end{array} \\ & \begin{array}{l}\text { a legal level.2. Promote } \\ \text { the use of European } \\ \text { Health Insurance Card } \\ \text { (EHIC) }\end{array}\end{array}$

Citizens: No No

External migrant workers: NA

Migrant worker, almost 1. Citizens: free $455 \mathrm{RMB}$ in $2015 \quad$ 2. External migrant workers: self

1. Citizens: free 2. External migrant workers: NA
Primarily the European Commission 
Table 3 international approaches implementing in other countries or territory (Continued)

\begin{tabular}{|c|c|c|c|c|c|}
\hline & USA & Kerala, India & Thailand & Australia & European Union \\
\hline & $\begin{array}{l}\text { composed of } \\
\text { approximately } 30 \mathrm{NACHC} \\
\text { members who represent } \\
\text { health centers that serve } \\
\text { the MSAW population. }\end{array}$ & & & & \\
\hline $\begin{array}{l}\text { Covered } \\
\text { services }\end{array}$ & $\begin{array}{l}\text { Community health } \\
\text { centers through 10,000 } \\
\text { clinic sites provide } \\
\text { culturally competent and } \\
\text { comprehensive primary } \\
\text { and preventive } \\
\text { healthcare to migratory } \\
\text { and seasonal farmworkers } \\
\text { and their families. The } \\
\text { program also emphasizes } \\
\text { the occupational health } \\
\text { and safety of this } \\
\text { population. }\end{array}$ & $\begin{array}{l}\text { Hospital services in } \\
\text { government hospital } \\
\text { or empaneled private } \\
\text { network hospital }\end{array}$ & $\begin{array}{l}\text { 1. Screening for and } \\
\text { treatment of certain } \\
\text { communicable diseases. } \\
\text { 2. Benefit package covers } \\
\text { comprehensive curative } \\
\text { services, including } \\
\text { antiretroviral therapy, and } \\
\text { a range of prevention } \\
\text { and health promotion } \\
\text { services, similar to the Tai } \\
\text { universal health coverage } \\
\text { scheme. }\end{array}$ & NA & Same with local residents \\
\hline Legal Basis & $\begin{array}{l}\text { Migrant and Seasonal } \\
\text { Agricultural Worker } \\
\text { Protection Act }\end{array}$ & & NA & NA & $\begin{array}{l}\text { Regulation (EC) No 883/ } \\
2004 \text {, and Regulation } \\
\text { (EC) No } 987 / 2009 \text { of the } \\
\text { European Parliament and } \\
\text { of the Council }\end{array}$ \\
\hline Results & $\begin{array}{l}\text { In } 2017 \text {, health centers } \\
\text { served } 972,251 \text { migrant } \\
\text { and seasonal farmworkers } \\
\text { and their families, of } \\
\text { which, } 872,565 \text {, or } \\
\text { approximately } 90 \% \text {, were } \\
\text { served by Migrant Health } \\
\text { Centers }\end{array}$ & $\begin{array}{l}\text { Migrant laborers } \\
\text { working in hotels, } \\
\text { footwear sector, and } \\
\text { other industries can } \\
\text { obtain this insurance } \\
\text { card by enrolling in } \\
\text { this scheme. }\end{array}$ & NA & NA & NA \\
\hline
\end{tabular}

contents involved are comprehensive. For instance, contents include how to treat migrant workers, the rights and interests to be guaranteed, how to handle people who are double covered by multiple countries or people not covered by any country, how to solve the problem of reimbursement for medical treatment in different areas, how to deal with the cumulative of the set period, and how to cooperate and exchange between institutions or countries. Therefore, the European Commission not only provides guidance but more importantly offers coordination.

\section{Discussion}

This systematic review reveals four important reasons behind the barriers to effective health insurance coverage for Chinese RUMWs. First, despite a decade of health care reforms, the Chinese health system is still greatly fragmented, which directly causes the low portability of SHI. Second, existing policies are not well compatible with RUMWs' inherent characteristics and health needs. Third, local governments and enterprises have a strong intention to provide full employment only to those RUMWs with the skills that they need; whereas for other RUMWs, without stable and full employment, they cannot be included in the healthcare insurance schemes in urban areas. Fourth, due to the results outlined above, RUMWs often suffer from high working mobility and low job stability and thus become more and more disadvantaged and marginalized, socially and economically, all of which work together, placing them in a vulnerable position.

The question is: how to change such a devastating situation for RUMWs in China? Here we propose three strategies.

\section{Increase the health insurance portability by reducing fragmentation}

The fragmentation of the Chinese health system has been discussed by many researchers $[6,28,105,106]$. To further this understanding, we divide the concept of fragmentation into two parts: differentiation and coordination. The former focuses on the differences among departments, regions, or institutions; and the latter focuses on the compatibility and consonance among them. Evidently, differentiation and coordination are mutually influenced by each other.

In China, a variance among different regions is evident, through the view of economic capacity or the institutional settings. To reduce fragmentation, the central government of China has to take more responsibility for coordination. How can this be achieved? The European experience is instructive here: by giving more details of policy. For China, 
the details should include: 1) methods to handle the amount of the risk-sharing account of UEBMI and the amount funded by government in NCMS; 2) methods to resolve the conflicts of interest between regions; and 3) addressing the issue of self-employed RUMWs.

In fact, the central government has already played the role of a coordinator, as the three main SHIs were managed by one agency. China's experience as a coordinator is evident in the raising of risk-sharing of NCMS from the county/municipal level to provincial level, as well as the implementation of reimbursements beyond jurisdictions. These examples indicate that the Chinese government has the potential to act as a good coordinator [104]. However, this has only happened within provinces, or between provinces, dependent on their willingness. A unified coordinator from the central government, as in the European Commission, is still absent.

Adopting the role of coordinator formally would increase the coordination between regions, and simultaneously weaken the influence of differentiation. To decrease the differentiation through integration, it is better to include the RUMWs into URBMI or NCMS in the flow-in area rather that integrate the MWHI into UEBMI.

\section{Make the policy more compatible with the characteristics and health needs of RUMWs}

Several contradictions or key problems need to be solved in the future: 1) if the RUMWs are included into the SHI in the flow-in area, the mismatch between the financing unit of NCMS or URBMI and the migrant unit of RUMW, as well as the mismatch between the yearly finance period and RUMW's high place mobility. Shenzhen's model is instructive in this approach; (2) when including the RUMWs into MWHI, ensuring that they are covered by outpatient services and that the funds contributed by RUMWs are transferable after they go back to their hometowns; 3) if keeping RUMWs covered by the NCMS in their flow-out area, ensuring that NCMS covers primary care out of the jurisdictions and not only inpatient care.

\section{Strengthen supervision on employers and create more opportunities for RUMWs}

Regarding the unwillingness of the local governments and business sectors to provide health insurance to all RUMWs, more detailed directions from the central government should be given to the local ones; meanwhile, the government should also strengthen the supervision [64], especially on private enterprises [58, 91, 107-110] and SMEs [68]. It is equally important to increase RUMWs' ability to negotiate with their employers by offering them more substantial or informative assistances [91], offering them more vocational training to reduce their mobility, increase their job stability $[91,111,112]$ and their willingness to settle in the cities $[64,65,71,90]$.

\section{Conclusions}

Currently, policy reforms in China are not favorable to RUMWs. The number of RUMWs almost accounts for one-fifth of China's total population, and around $90 \%$ of them are covered by health insurance. However, in relation to insurance cover in their flow-in areas, this percentage reduced to only about $20 \%$. In this study, we summarized why and how RUMWs was selectively included into the local health insurance. By focusing on health insurance portability and fragmentation, we summarized why and how there is a mismatch of the existing insurance with RUMWs' characteristics or health needs, as well as the game among stakeholders that place RUMWs between the cracks, without much space to choose. By sorting out and comparing current policies, we summarized why current policy reform in China is not favorable to RUMWs. We also summarized domestic and international innovative approaches that can be helpful for increasing the effective coverage on RUMWs. A series of theoretical analysis and derivation were also conducted with the aim of improving the effective coverage of health insurance for RUMWs, and the primary suggested strategies were recommended.

A few limitations of this study could be addressed in future research. First, a lack of quantitative data impeded the provision of more detailed suggestions. For instance, we emphasized that the government should increase supervision of enterprises and job training for RUMWs, but we could not clearly point out which enterprises and what kinds of training. Second, we did not focus on information related to RUMW' age, gender, education, and migration between or within provinces. Studies have indicated the influence of these factors on the concept and attitude towards health insurance [30, 31, 88, 113115], but the inconsistent results are difficult to synthesize. Third, in the search of fundamental reasons, this study was not only limited to the health sector itself, but also investigated the problem from a broader view of socioeconomic and institutional structures. However, a broader view requires further studies from cross-cutting scholars. Fourth, we found that RUMWs have worse mental health than local people, and their health needs are delayed, but we failed to provide suggestions on how to cover their mental health and how to handle their delayed health need, due to a lack of related studies.

This is still the first study which systematically summarized the barriers faced by RUMWs in being effectively included by health insurance, and simultaneously discussed how to overcome existing barriers. This study will be helpful of not only for China's UHC business, but 
also other countries', as the barriers faced by migrant workers share commonalities internationally.

\section{Supplementary information}

Supplementary information accompanies this paper at https://doi.org/1 0.1186/s12889-020-8448-8

Additional file 1. Search Strategy and study selection

\section{Abbreviations}

CASP: Critical appraisal skills programme; CERQual: Confidence in the evidence from reviews of qualitative research; GDP: Gross domestic product; GRADE: Grading of recommendations assessment, development, and evaluation; MWHI: Migrant work health insurance; NCMS: New-rural cooperative medical scheme; $\mathrm{NIH}$ : National institutes of health; PRISMA: Preferred reporting items for systematic reviews and meta-analysis; RUMWs: Rural-to-urban migrant workers; SHI: Social health insurances: SMES: Small and medium-sized enterprises; SQAT: Study quality assessment tools; UEBMI: Urban employee-based basic medical insurance; UHC: Universal health coverage; URBMI: Urban resident-based basic medical insurance; WHO: World Health Organization

\section{Acknowledgements}

Not applicable.

\section{Authors' contributions}

SC and QY designed the Review structure. SC, QY and LX did the information collection. SC and DD wrote the initial manuscript. YC, ZF, ZW, $J Z$, JJ, QY, LX, LY, JS, XC, LZ, HF, and LW contributed to the revision of the manuscript. The authors read and approved the final manuscript.

\section{Funding}

Not applicable.

\section{Availability of data and materials}

Not applicable.

\section{Ethics approval and consent to participate}

Not applicable.

\section{Consent for publication}

Not applicable.

\section{Competing interests}

The authors declare that they have no competing interests.

\section{Author details}

${ }^{1}$ The School of Clinical Medicine, University of Cambridge, Cambridge, UK. ${ }^{2}$ School of Public Health, Fudan University, Shanghai, China. ${ }^{3}$ School of Medicine and Health Management, Tongji Medical College, Huazhong University of Science and Technology, Wuhan, China. ${ }^{4}$ Department of Health Policy and Management, Yale School of Public Health, New Haven, Connecticut, USA. ${ }^{5}$ Research Center for Healthcare Management, School of Economic and Management, Tsinghua University, Beijing, China. ${ }^{6}$ Guizhou Provincial Institute of Health Development, Guizhou Medical University, Guiyang, Guizhou, China. ${ }^{7}$ School of Social Development and Public Policy, Fudan University, Shanghai, China. ${ }^{8}$ Department of Sociology, Tsinghua University, Beijing, China. ${ }^{9}$ School of Political Science and Public Administration, Wuhan University, Wuhan, Hubei, China. ${ }^{10} \mathrm{Health}$ Bureau, Macao SAR, China. ${ }^{11}$ State Key Laboratory for Diagnosis and Treatment of Infectious Diseases, National Clinical Research Center for Infectious Diseases, Collaborative Innovation Center for Diagnosis and Treatment of Infectious Diseases, The First Affiliated Hospital, College of Medicine, Zhejiang University, Hangzhou, Zhejiang, China. ${ }^{12}$ The Jockey Club School of Public Health and Primary Care, Faculty of Medicine, The Chinese University of Hong Kong, Hong Kong SAR, China.
Received: 26 August 2019 Accepted: 3 March 2020

Published online: 30 March 2020

\section{References}

1. World Health Organization. Regional Office for the Western Pacific. Monitoring universal health coverage and health in the sustainable development goals: baseline report for the Western Pacific Region 2017. 2017. [https://iris.wpro.who. int/bitstream/10665.1/13963/1/9789290618409-eng.pdf]. Accessed 30 July 2019.

2. World Health Organization. The World Health Report-financing for universal coverage. Geneva: World Health Organization; 2010. p. 23-5.

3. Wang HH, Summerskill W. Health-care reform in China: a call for papers. Lancet. 2018;392(10164):2535

4. Chinese Communist Party Central Committee (CCPCC) and State Council (SC). The CCPCC and the State Council publish Healthy China 2030 Planning Outline, October 25, 2016 [http://www.gov.cn/zhengce/2016-10/25/ content_5124174.htm]. Accessed 30 July 2019.

5. Yu H. Universal health insurance coverage for 1.3 billion people: what accounts for China's success? Health Policy. 2015;119(9):1145-52.

6. Meng QY, Fang H, Liu XY, Yuan BB, Xu J. Consolidating the social health insurance schemes in China: towards an equitable and efficient health system. Lancet. 2015;386(10002):1484-92.

7. Zhao C, Wang C, Shen C, Wang Q. China's achievements and challenges in improving health insurance coverage. Drug Discov Ther. 2018;12(1):1-6.

8. Qin XZ, Pan J, Liu GG. Does participating in health insurance benefit the migrant workers in China? An empirical investigation. China Econ Rev. 2014; 30:263-78.

9. Zeng J, Shi L, Zou X, Chen W, Ling L. Rural-to-Urban migrants' experiences with primary care under different types of medical Institutions in Guangzhou, China. PLoS ONE. 2015;10:e0140922

10. Jin Y, Hou Z, Zhang D. Determinants of Health insurance coverage among people aged 45 and over in China: who buys public, private and multiple insurance. PLoS ONE. 2016;11:e0161774. https://doi.org/10.1371/journal. pone.0161774.

11. Chen W, Zhang Q, Renzaho AMN, Zhou F, Zhang H, Ling L. Social health insurance coverage and financial protection among rural-to-urban internal migrants in China: evidence from a nationally representative cross-sectional study. BMJ Glob Health. 2017;2:e000477. https:/doi.org/10.1136/bmjgh-2017-000477.

12. Zhang AW, Nikoloski Z, Mossialos E. Does health insurance reduce out-ofpocket expenditure? Heterogeneity among China's middle-aged and elderly. Soc Sci Med. 2017;190:11-9.

13. Zhong C, Kuang L, Li L, Liang Y, Mei J, Li L. Equity in patient experiences of primary care in community health centers using primary care assessment tool: a comparison of rural-to-urban migrants and urban locals in Guangdong, China. Int J Equity Health. 2018:17:51. https://doi.org/10.1186/s12939-018-0758-4.

14. Li Y, Wu SF. Migration and health constraints in China: a social strata analysis. J Contemporary China. 2010:19(64):335-58.

15. Li Y. Understanding health constraints among rural-to-urban migrants in China. Qual Health Res. 2013;23(11):1459-69.

16. Li Y. Illegal private clinics: ideal health services choices among rural-urban migrants in China? Soc Work Public Health. 2014;29(5):473-80.

17. Liang Y, Guo ML. Utilization of health services and health-related quality of life research of rural-to-urban migrants in China: a cross-sectional analysis. Soc Indic Res. 2015:120(1):277-95.

18. Zhang L, Wu M. Analysis on status and determinants of self-treatment of rural floating population in Beijing. Beijing Da Xue Xue Bao Yi Xue Ban. 2015;47(3):4550-458

19. Zou G, Zeng Z, Chen W, Ling L. Self-reported illnesses and service utilisation among migrants working in small-to medium sized enterprises in Guangdong, China. Public Health. 2015:129(7):970-8.

20. Song XL, Zou GY, Chen W, Han SQ, Zou X, Ling L. Health service utilisation of rural-to-urban migrants in Guangzhou, China: does employment status matter? Tropical Med Int Health. 2017;22(1):82-91.

21. Peng Y, Chang W, Zhou H, Hu H, Liang W. Factors associated with healthseeking behavior among migrant workers in Beijing, China. BMC Health Serv Res. 2010;10:69. https://doi.org/10.1186/1472-6963-10-69.

22. Zhang $X, Y u$ B, He T, Wang P. Status and determinants of health services utilization among elderly migrants in China. Global Health Research and Policy. 2018;3:8.

23. Bork-Huffer T, Kraas F. Health care disparities in Megaurban China: the ambivalent role of unregistered practitioners. Tijdschr Econ Soc Geogr. 2015; 106(3):339-52 
24. Tang $C, X u$ J, Zhang $M$. The choice and preference for public-private health care among urban residents in China: evidence from a discrete choice experiment. BMC Health Serv Res. 2016;16:580. https://doi.org/10.1186/s12913-016-1829-0.

25. Ouyang W, Wang BY, Tian L, Niu XY. Spatial deprivation of urban public services in migrant enclaves under the context of a rapidly urbanizing China: An evaluation based on suburban Shanghai. Cities. 2017;60:436-45.

26. Zhao DH, Rao KQ, Zhang ZR. Coverage and utilization of the health insurance among migrant workers in Shanghai, China. Chinese Med J. 2011;124(15):2328-34.

27. Zhou C, Chu J, Liu J, Gai Tobe R, Gen H, Wang X, et al. Adherence to tuberculosis treatment among migrant pulmonary tuberculosis patients in Shandong, China: a quantitative survey study. PLoS ONE. 2012;7:e52334. https://doi.org/10.1371/journal.pone.0052334.

28. Bork T, Kraas F, Yuan Y. Governance challenges in China's Urban health care system - the role of stakeholders. Erdkunde. 2011;65(2):121-35.

29. Tobe RG, Xu LZ, Zhou CC, Yuan Q, Geng H, Wang XZ. Factors affecting patient delay of diagnosis and completion of direct observation therapy, short-course (DOTS) among the migrant population in Shandong, China. Biosci Trends. 2013;7(3):122-8.

30. Fang $H$, Jin $Y$, Zhao $M$, Zhang H, A Rizzo J, Zhang D, Hou Z. Does migration limit the effect of health insurance on hypertension management in China? Int J Environ Res Public Health. 2017. https://doi.org/10.3390/ijerph14101256.

31. Qian Y, Ge D, Zhang L, Sun L, Li J, Zhou C. Does Hukou origin affect establishment of health records in migrant inflow communities? A nationwide empirical study in China. BMC Health Serv Res. 2018;18:704. https://doi. org/10.1186/s12913-018-3519-6.

32. Zhao MF, Liu SH, Qi W. Spatial differentiation and influencing mechanism of medical care accessibility in Beijing: a migrant equality perspective. Chin Geogr Sci. 2018;28(2):353-62.

33. Guan M. Should the poor have no medicines to cure? A study on the association between social class and social security among the rural migrant workers in urban China. Int J Equity Health. 2017;16:193. https://doi. org/10.1186/s12939-017-0692-x.

34. Li Y, Wu SF. Social networks and health among rural-urban migrants in China: a channel or a constraint? Health Promot Int. 2010;25(3):371-80.

35. He S. Institutional segregation and intergenerational division: effects of medical insurance participation on the utilization of inpatient medical Services in Floating Population. Shanghai: East China University Of Science and Technology; 2018

36. Ministry of Human Resources and Social Security of the People's Republic of China. Interim measures for the transferability of basic medical insurance account among internal migrants. 2009. [http://www.mohrss.gov.cn/gkml/ xxgk/201407/t20140717_136139.htm]. Accessed 30 July 2019.

37. Ministry of Human Resources and Social Security of the People's Republic of China. Interim measures for the transfer and continuation of basic medical security relationships of migrant employees. 2016. [http://www.mohrss.gov. cn/SYrlzyhshbzb/shehuibaozhang/zcwj/yiliao/201606/t20160630_242630. html]. Accessed 30 July 2019.

38. Huang YQ, Guo F. Welfare Programme participation and the wellbeing of non-local rural migrants in metropolitan China: a social exclusion perspective. Soc Indic Res. 2017;132(1):63-85.

39. Bao HJ, Fang Y, Ye QY, Peng Y. Investigating social welfare change in Urban Village transformation: a rural migrant perspective. Soc Indic Res. 2018; 139(2):723-43.

40. Niu JL, Qi YQ. Internal migration and health stratification in urban China. Asian Pac Migr J. 2015;24(4):432-62

41. Ministry of Human Resources and Social Security of the People's Republic of China. 2018 Statistical Bulletin on the Development of Human Resources and Social Security. 2019. [http://www.mohrss.gov.cn/SYrlzyhshbzb/zwgk/ szrs/tjgb/201906/W020190611539807339450.pdf ]. Accessed 30 July 2019.

42. Schilgen B, Nienhaus A, Handtke O, Schulz H, Mosko M. Health situation of migrant and minority nurses: a systematic review. PLoS One. 2017;12(6): e0179183.

43. Seedat F, Hargreaves S, Nellums LB, Ouyang J, Brown M, Friedland JS. How effective are approaches to migrant screening for infectious diseases in Europe? A systematic review. Lancet Infect Dis. 2018;18:e259-71. https://doi. org/10.1016/S1473-3099(18)30117-8

44. Fitzgerald S, Chen X, Qu H, Sheff MG. Occupational injury among migrant workers in China: a systematic review. Injury Prevention. 2013;19(5):348-54.

45. Markkula N, Cabieses B, Lehti V, Uphoff E, Astorga S, Stutzin F. Use of health services among international migrant children-a systematic review. Glob Health. 2018;14(1):52.
46. Edward J, Hines-Martin V. Examining perceived barriers to healthcare access for Hispanics in a southern urban community. J Hosp Admin. 2016;5(2):102.

47. Levesque J-F, Harris MF, Russell G. Patient-centred access to health care: conceptualising access at the interface of health systems and populations. Int J Equity Health. 2013;12(1):18.

48. Anyinam C. Availability, accessibility, acceptability, and adaptibility: four attributes of African ethno-medicine. Soc Sci Med. 1987;25(7):803-11.

49. Organization WH: Monitoring the building blocks of health systems: a handbook of indicators and their measurement strategies: World Health Organization; 2010.

50. National Heart, Lung, and Blood Institute. Study Quality Assessment Tools [https://www.nhlbi.nih.gov/health-topics/study-quality-assessment-tools]. Accessed 30 July 2019

51. Singh J. Critical appraisal skills programme. J Pharmacol Pharmacother. 2013:4(1):76.

52. Guyatt G, Oxman AD, Akl EA, Kunz R, Vist G, Brozek J, Norris S, Falck-Ytter Y, Glasziou P, Jaeschke R. GRADE guidelines: 1. Introduction-GRADE evidence profiles and summary of findings tables. J Clin Epidemiol. 2011;64(4):383-94.

53. Lewin S, Booth A, Glenton C, Munthe-Kaas H, Rashidian A, Wainwright M, et al. Applying GRADE-CERQual to qualitative evidence synthesis findings: introduction to the series. Implement Sci. 2018;13:2. https://doi.org/10.1186/ s13012-017-0688-3.

54. Liu YF, Dijst M, Geertman S. Residential segregation and well-being inequality over time: a study on the local and migrant elderly people in Shanghai. Cities. 2015;49:1-13.

55. National Bureau of Statistics. 2016 Investigation report on rural-to-urban migrant workers. 2017. [http://www.stats.gov.cn/tjsj/zxfb/201704/t2017042 8_1489334.html]. Accessed 30 July 2019.

56. Hussain A. Social welfare in China in the context of three transitions. How far across the river; 2003. p. 273-312.

57. Cheng ZM, Nielsen I, Smyth R. Access to social insurance in urban China: a comparative study of rural-urban and urban-urban migrants in Beijing. Habitat Int. 2014:41:243-52.

58. Gao Q, Yang S, Li S. Social insurance for migrant workers in China: impact of the 2008 labour contract law. Econ Political Stud-Eps. 2017:5(3):285-304.

59. Chen J. Internal migration and health: re-examining the healthy migrant phenomenon in China. Soc Sci Med. 2011;72(8):1294-301.

60. Ma S, Zhou X, Jiang M, Li Q, Gao C, Cao W, Li L. Comparison of access to health services among urban-to-urban and rural-to-urban older migrants, and urban and rural older permanent residents in Zhejiang Province, China: a cross-sectional survey. BMC Geriatr. 2018;18:174. https://doi.org/10.1186/ s12877-018-0866-4.

61. Liu RG, Li YW, Wangen KR, Maitland E, Nicholas S, Wang J. Analysis of hepatitis $B$ vaccination behavior and vaccination willingness among migrant workers from rural China based on protection motivation theory. Hum Vaccin Immunother. 2016:12(5):1155-63.

62. Xue H, Hager J, An Q, Liu K, Zhang J, Auden E, et al. The quality of tuberculosis care in urban migrant clinics in China. Int J Environ Res Public Health. 2018;15(9):2037. https://doi.org/10.3390/ijerph15092037.

63. Wang Y, Cochran C, Xu P, Shen JJ, Zeng G, Xu Y, et al. Acquired immunodeficiency syndrome/human immunodeficiency virus knowledge, attitudes, and practices, and use of healthcare services among rural migrants: a cross-sectional study in China. BMC Public Health. 2014;14:158. https://doi.org/10.1186/1471-2458-14-158.

64. Huang YQ, Cheng ZM. Why are Migrants' not participating in welfare programs? Evidence from Shanghai, China. Asian Pac Migr J. 2014;23(2):183-210.

65. Huang $Z Y$, Pan ZH. Improving migrants' access to the public health insurance system in China: a conceptual classification framework. Asian Pac Migr J. 2017;26(2):274-84.

66. Rickne J. Labor market conditions and social insurance in China. China Econ Rev. 2013;27:52-68.

67. Jing M, Wu M. Analysis of the influence factors of buying choice of insurance paying unit for farmer workers. Chinese Health Econ. 2011;30(10):41-4.

68. Wu S, Wang P, Ling L. Research on factors affected migrant workers in SMES participating urban medical insurance in the PRD areas. Stud Hong Kong and Macao. 2012;9:54-66.

69. Liu Z. Empirical study on the status and problems of medical insurance for the new-generation of migrant rural workers. Chinese Health Serv Manag. 2013:30(08):585-7.

70. Sun $\mathrm{H}$. The research on the problem of medical insurance for migrant workers. Changsha: Central South University of Forestry and Technology; 2013. 
71. LU X-j, Liu H-y. Investigation and research on the influencing factors of migrant Workers' participation in basic medical insurance for urban employers. Chinese Health Econ. 2018;37(4):19-21.

72. Yang $Q$, Qin L. Analysis on the influencing factors of the utilization of migrant Workers' medical services: taking the Yangtze River Delta as an example. J Shandong University of Technology (social sciences). 2016; 32(2):63-9.

73. Kuang-shi $\mathrm{H}, \mathrm{Ri}-\mathrm{da} \mathrm{G}$ : Social security trap of migration and migration trap of social security. In: West Forum: 2011; 2011: 1-8

74. Wang J, Zheng J, Wang P, Qi L. Migration and health in China: bridging the gaps in policy aims and the reality of medical services to migrants. Public Adm Rev. 2014;07(04):29-45 182-183.

75. The State Council of the People's Republic of China. Opinions on integrating the basic medical insurance system for urban and rural residents. 2016. [http://www.mohrss.gov.cn/gkml/xxgk/201601/t2016 0112_231624.htm]. Accessed 30 July 2019.

76. Ministry of Human Resources and Social Security of the People's Republic of China. Implementation of the "Opinions on Integrating the Basic Medical Insurance System for Urban and Rural Residents." 2016. [http://www.mohrss. gov.cn/SYrlzyhshbzb/shehuibaozhang/zcwj/yiliao/201601/t20160114_231 766.html]. Accessed 30 July 2019

77. Wei T. A comparative study on the portability of migrant Workers' medical insurance. Beijing: Capital University of Economics and Business; 2015.

78. Migrant Population Service Center, National Health Commission of the People's Republic of China. China migrants dynamic survey. [http://www. chinaldrk.org.cn/wjw/\#/data/classify/population]. Accessed 30 July 2019.

79. National Healthcare Security Administration, Ministry of Finance, Ministry of Human Resources and Social Security, and National Health Commission. Notice on implementing the work of basic medical insurance for urban and rural residents. 2018. [http://www.law-lib.com/law/law_view.asp?id=631983]. Accessed 30 July 2019

80. Sun L, Chi J. Analysis on transfer and continuing of social medical insurance system for migrants: a comparative study based on the policies of 31 provincial capitals and municipalities. Lanzhou Academic. 2016;03:196-208.

81. World Bank: The path to integrated Insurance Systems in China; 2010.

82. Han Y, Zhang X, Gao Y, Zhang Y, Zhang Y, Qu X. Cross-sectional investigation on social security of decorating Workers in Hebei Province. $J$ Prev Med Inform. 2012;28(02):81-3.

83. You C. Research on medical Insurance for Immigrant Workers in China. Northwest Population J. 2009;30(04):33-7.

84. Zhou M, Cao L. Analysis of factors affecting the choice of medical insurance plan for migrant Workers in Hangzhou. Chinese J Hospital Administration. 2010;9:678-80.

85. Jiang H. Comparative Analysis of Migrant Workers Participating in Medical Insurance for Urban Employees. Health Econ Res. 2016;12:29-33.

86. Zhao X, Ming D, Ma W. Influential factors of outpatient service utilization and expenses of middle-aged and elderly migrant workers in China. J Peking University (Health Sciences). 2015;47(3):464-8.

87. Zhou Q, Qin X, Yuan Y. Migrant Workers' real Accessibiltiy to medical services: based on the special survey of rural-to-urban migrant Workers in Beijing. Insurance Stud. 2013;09:112-9.

88. Wang H, Zhang D, Hou Z, Yan F, Hou Z. Association between social health insurance and choice of hospitals among internal migrants in China: a national cross-sectional study. BMJ Open. 2018;8:e018440. https://doi.org/10. 1136/bmjopen-2017-018440.

89. Shao S, Zhang H, Zhao X, Du J, Zhao Y. Research on the current situation and needs of migrant workers to participate in medical insurance in one district of Beijing. China Medical Herald. 2016;13(32):49-52.

90. Sun J. The Reason for Low Coverage of Social Insurance for Rural Migrant Workers: From a Persective of Citizenization and insurance arrangements. J Soc Dev. 2015;2(02):142-59 244-245.

91. Qin L, Qin X, Hui Y. The determinants on the migrant Workers' participation in the medical Insurance for Urban Employees. Social Securitxy Res. 2014;20(02):104-10.

92. Shanghai Human Resources and Social Security Bureau. Interim measures for comprehensive insurance for migrant workers in Shanghai. 2004. [https:// shanghai.chashebao.com/ziliao/17499.html\#z1]. Accessed 30 July 2019.

93. Shanghai Municipal Peoples Government. Decision on amending the interim measures for comprehensive insurance for migrant workers in Shanghai. 2004. [http://www.shanghai.gov.cn/nw2/nw2314/nw2319/nw24 07/nw12938/u26aw27506.html]. Accessed 30 July 2019.
94. Shanghai Human Resources and Social Security Bureau. Implementation opinion on daily medical expenses subsidy for comprehensive insurance for employees in Shanghai. 2005. [http://www.12333sh.gov.cn/201712333/xxgk/ flfg/gfxwj/shbx/07/201711/t20171103_1271189.shtml]. Accessed 30 July 2019.

95. Shanghai Municipal People's Government. Notice concerning the participation of foreign employees in the basic medical insurance for employees in this Municipality. 2011. [http://www.12333sh.gov.cn/201 712333/xxgk/flfg/szfgz/01/201711/t20171103_1269786.shtml]. Accessed 30 July 2019.

96. Shanghai Human Resources and Social Security Bureau. Shanghai social insurance payment standard. 2018. [http://sh.bendibao.com/zffw/201643/15 8733.shtm]. Accessed 30 July 2019.

97. Beijing Human Resources and Social Security Bureau. Interim measures for participation in basic medical insurance for migrant workers in Beijing. 2004 [http://www.bjrbj.gov.cn/csibiz/home/static/articles/catalog_75800/201108-16/article ff80808130e8e3660130f7f3b2a80246/ff80808130e8e366013 of7f3b2a80246.html]. Accessed 30 July 2019.

98. Beijing Human Resources and Social Security Bureau. Notice on the issue of migrant workers participating in basic medical insurance. 2012. [http://www. bjrbj.gov.cn/csibiz/home/static/articles/catalog_75200/2012-03-20/article_ ff80808132cceaf801362e3f334b015b/ff80808132cceaf801362e3f334b015b. html]. Accessed 30 July 2019.

99. Beijing Human Resources and Social Security Bureau. Social insurance payment standards in Beijing. 2018. [http://bj.bendibao.com/zffw/201866/25 0275.shtm]. Accessed 30 July 2019.

100. Shenzhen Municipal People's Government. Interim measures for medical insurance of Shenzhen laborers. 2006. [http://www.sz.gov.cn/zfgb/2006/gb4 98/200810/t20081019_94368.htm]. Accessed 30 July 2019.

101. Shenzhen Municipal People's Government. Social insurance measures in Shenzhen. 2013. [http://www.sz.gov.cn/zfgb/2013/gb857/201311/t2 0131113 2245934.htm]. Accessed 30 July 2019.

102. Shenzhen Social Insurance Fund Administration. Shenzhen social insurance payment standard. 2018. [http://bsy.sz.bendibao.com/bsyDetail/618587. html]. Accessed 30 July 2019.

103. International Labour Organization. Coordination of Social Security Systems in the European Union: An explanatory report on EC Regulation No 883/ 2004 and its Implementing Regulation No 987/2009. 2010. [https://www.lo. org/wcmsp5/groups/public/---europe/---ro-geneva/---sro-budapest/ documents/publication/wcms_166995.pdf]. Accessed 30 July 2019.

104. Lijian Q, Xuewen W. Research on non-local transfer of basic medical Insurance of Migrant Workers: China's lessons from the EU experiences. Academic Monthly. 2015;11:7.

105. Yip W, Hsiao W. Harnessing the privatisation of China's fragmented healthcare delivery. Lancet. 2014;384(9945):805-18.

106. Hsiao W, Shaw RP. Social health insurance for developing nations: The World Bank; 2007.

107. Zhao Y, Gao G. Factors affecting migrant Workers' participation in basic medical Insurance for Urban Employees [Chinese]. J Shandong Administration College. 2018;03:93-9.

108. Luo J. Research on the influencing factors of migrant workers participating in Urban Workers' medical insurance. Res World. 2015;03:42-6.

109. Lijian Q, Yun H, Zhen W. Analysis on participation rate and determinants of social Insurance of Migrant Population in China. Stat Res. 2015;32(1):68-72.

110. Guo F, Zhang Z. One decade of the reform of social insurance and social protection policies for migrants: evidence from four major cities in China. Population Res. 2013;37(3):29-42.

111. Liu Y, Qin L. Analysis of the influencing factors of migrant workers' absence from the local town medical insurance. J Guangxi Sci Technology Normal University. 2016;31(4):60-5.

112. Wang $H$, Chen $Y$. An analysis on the work welfare discrimination against migrants. Chinese J Population Sci. 2010;2:47-54.

113. Zhang $R$, Zhang J. Research on medical security and insured behavior of new generation migrant workers_- - based on the investigation of three dimensions of risk attitude, health status and work industry [Chinese]. Shanghai Insurance. 2018;10:50-7.

114. Wang S. A study on the willingness to participate in the social insurance participation of migrant workers and the influencing factors: a case study of Xinxiang City, Henan Province. J China Institute of Industrial Relations. 2017; 31(04):43-9. 
115. Yang Y, Li Y. Population characteristics and institutional participation: how does migrant Wokrers make a choice under health insurance policy in China? Soc Security Res. 2013;17(01):135-47.

\section{Publisher's Note}

Springer Nature remains neutral with regard to jurisdictional claims in published maps and institutional affiliations.

Ready to submit your research? Choose BMC and benefit from:

- fast, convenient online submission

- thorough peer review by experienced researchers in your field

- rapid publication on acceptance

- support for research data, including large and complex data types

- gold Open Access which fosters wider collaboration and increased citations

- maximum visibility for your research: over $100 \mathrm{M}$ website views per year

At $\mathrm{BMC}$, research is always in progress. 